\title{
Chronic kidney disease pada kucing domestic short hair
}

\author{
Andrea Puput Handayani ${ }^{1}$, Vici Eko Handayani ${ }^{2}$, Tiara Widyaputri ${ }^{3, *}$ \\ ${ }^{1}$ Program Pendidikan Profesi Dokter Hewan, Fakultas Kedokteran Hewan, Universitas Brawijaya, Malang \\ ${ }^{2}$ Praktisi Klinik Hewan Citrapet and Vet, Cibubur, Bekasi \\ ${ }^{3}$ Fakultas Kedokteran Hewan, Universitas Brawijaya, Malang
}

\begin{abstract}
ABSTRAK: Chronic kidney disease (CKD) merupakan kelainan struktural dan fungsional ginjal yang bersifat irreversibel, sehingga ginjal mengalami penurunan hingga kehilangan fungsinya. Kasus ini ditulis untuk melaporkan proses penentuan diagnosa dan penanganan CKD pada kucing di klinik hewan Citrapet and Vet, Cibubur, Bekasi. Seekor kucing luar ruangan berkelamin betina dibawa ke klinik hewan dengan keluhan kondisi lemas dan tidak mau makan selama 3 hari. Temuan klinis menunjukkan turgor kulit $>2$ detik, diare, banyak pinjal, saluran cerna kosong dan banyak gas, serta ginjal teraba berukuran besar. Pemeriksaan hematologi dan kimia darah terjadi penurunan kadar hemoglobin, penurunan hematokrit, leukositosis, limfositosis, granulositosis dan azotemia. Pemeriksaan urinalisis diperoleh nilai BJ dibawah normal, hematuria, proteinuria dan leukosituria. Pencitraan ultrasonografi menunjukkan batas antara pelvis renal, korteks dan medula tidak jelas pada kedua ginjal dan pola anekhoik yang diduga cairan tampak pada ginjal kanan. Kucing didiagnosa CKD dengan prognosa infausta. Terapi yang diberikan adalah pemberian antibiotik, antidiare, probiotik dan suplemen ginjal. Pemilik memutuskan rawat jalan setelah perawatan selama 10 hari dengan kondisi letargi, nafsu makan buruk dan sudah tidak menggalami diare.
\end{abstract}

Kata kunci:

Kucing, ginjal, chronic kidney disease

\section{- PENDAHULUAN}

Chronic kidney disease (CKD) adalah penyakit yang umum terjadi pada kucing. Prevalensi CKD pada kucing bervariasi antara 1-3\%, meningkat pada usia 10 tahun menjadi 7,5\% dan mencapai antara 15 dan $30 \%$ pada usia di atas 15 tahun (Paepe 2014). Kucing biasanya tidak menunjukkan gejala klinis CKD hingga telah mencapai stadium penyakit lanjut. Gejala klinis berupa poliuria, polidipsia, penurunan berat badan, anoreksia parsial dan kelesuan yang berkembang pada stadium 2 dan 3 . Poliuria dan polidipsia merupakan tanda awal CKD yang sering terabaikan oleh pemilik. Tanda klinik yang lebih sering dan parah pada kucing dengan CKD stadium 4 yaitu muntah dan letargi (IRIS 2017). Tulisan ini melaporkan penanganan pada kasus CKD pada kucing.

\section{- KASUS}

Anamnesa dan sinyalemen: Seekor kucing bernama Kiabi dibawa ke Klinik Hewan Citrapet \& Vet dengan kondisi lemas dan sudah 3 hari tidak mau makan. Kiabi merupakan kucing liar yang biasanya datang untuk makan. Pemeriksaan fisik dan penunjang: Kiabi memiliki berat badan $2,05 \mathrm{~kg}$, suhu $38,8^{\circ} \mathrm{C}$, turgor $>2$ detik, mukosa pale, frekuensi napas $48 \mathrm{x} /$ menit, pulsus $96 \mathrm{x} /$ menit serta CRT $>2$ detik, anoreksia, dehidrasi, diare, dan ditemukan banyak pinjal. Palpasi abdomen terasa saluran cerna kosong, banyak gas, dan ginjal teraba besar. Observasi kucing Kiabi pada hari ke-2 menunjukkan polidipsi dan poliuria.
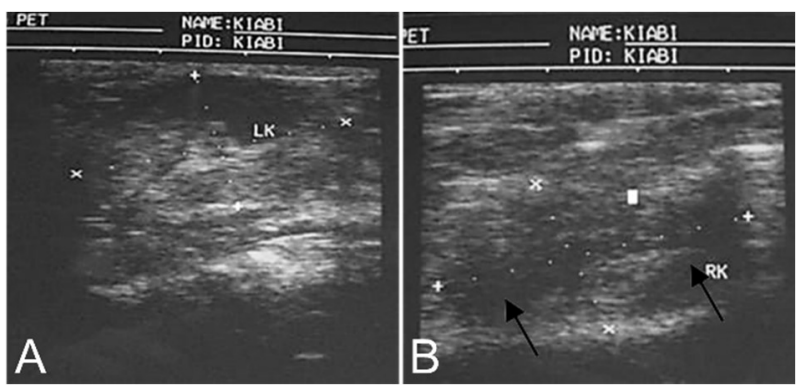

Gambar 1 Sonogram ginjal kiri (A) dan kanan (B) kucing

Pemeriksaan hematologi menunjukkan leukositosis diikuti limfositosis, granulositosis, penurunan hemoglobin dan hematokrit (anemia), trombositopenia; pemeriksaan kimia darah menunjukkan azotemia (peningkatan kreatinin dan ureum); Urinalisis menunjukkan BJ urin 1.016, hematuria, proteinuria dan leukosituria; pencitraan USG terlihat batas antara pelvis renal, korteks dan medula tidak jelas pada kedua ginjal (Gambar 1), serta pola tidak teratur pada ginjal kanan bersifat anekhoik (tanda panah) (Gambar 1B). Diagnosa: Chronic Kidney Disease. Prognosa: Infausta. Terapi: Penanganan pertama pada Kiabi adalah pemberian cairan ringer laktat $\pm 100 \mathrm{ml}$. Obat-obatan yang digunakan selama masa observasi yaitu propectalin ${ }^{\circledR}$ (probiotik dan kaolin pectin), clavamox ${ }^{\circledR}$ (clavulanate potassium dan amoxcilin

Diterima: 05-03-2021 | Direvisi: 20-04-2021 | Disetujui: 25-04-2021

(C) 2021 CC-BY-SA. Ini adalah artikel Open Access yang didistribusikan berdasarkan ketentuan dari Creative Commons Attribution ShareAlike 4.0 International License (https://creativecommons.org/licenses/by-sa/4.0/). 
tryidrate), dan renovet ${ }^{\circledR}$ (suplemen ginjal). Pakan basah yang diberikan yaitu recovery. Pemilik memutuskan membawa pulang dan melakukan rawat jalan setelah 10 hari.

\section{- HASIL DAN PEMBAHASAN}

Gejala awal CKD umumnya poliuria dengan polidipsia kompensatorik, anoreksia, letargi, kaheksia, dan yang jarang ditemui pada awal CKD tetapi umum pada fase lanjutan yaitu gejala gastrointestinal. Pemeriksaan fisik pada hewan CKD menunjukkan berkurangnya massa otot akibat status nutrisi, murmur jantung akibat kondisi anemia atau hipertensi, dehidrasi karena terbuangnya cairan pada proses poliuria, dan perubahan ukuran serta bentuk dari organ ginjal dengan ada maupun tidaknya rasa sakit (Foster 2013).

Diagnostik standar untuk ginjal yaitu pemeriksaan darah lengkap, biokimia serum, dan urinalisis. Ultrasonografi (USG) dan radiografi juga digunakan sebagai diagnosis dini untuk menegakkan diagnosa. Umumnya, pemeriksaan darah lengkap menunjukkan anemia (Nelson \& Couto 2013). Pemeriksaan biokimia serum lebih diarahkan pada peningkatan BUN dan kreatinin yang berhubungan dengan kondisi azotemia (Geetha 2008). Urinalisis dilakukan dengan mempertimbangkan konsentrasi urin, $\mathrm{pH}$, dan keberadaan protein, sel darah, bakteri, dan sel lain yang umumnya tidak boleh ditemukan dalam urin (Cornell Feline Health Center 2019). Gambaran USG pada ginjal normal dapat dibedakan antara korteks dan medula karena akan berbentuk khas seperti kumbang (Colville \& Bassert 2016).

Patomekanisme CKD secara pasti belum diketahui, namun jumlah nefron berkurang sekitar 25\% (Little 2012). Nefron normal yang tersisa dikompensasi dengan dilatasi arteriol glomerulus, peningkatan tekanan kapiler intraglomerular, peningkatan aliran plasma ginjal dan peningkatan Glomerulo Filtration Rate (GFR) nefron tunggal disebut hiperfiltrasi. Hiperfiltrasi meningkatkan kejernihan limbah nitrogen pada setiap nefron yang masih berfungsi, tetapi terjadi peningkatan kapiler intraglomerular dan kehilangan protein melalui glomerulus. Kelebihan protein yang disaring akan diserap kembali oleh sel-sel epitel tubulus kontortus proksimal (PCT), dipecah oleh lisosom seluler, dan akan masuk kembali darah sebagai asam amino. Proses pemecahan protein akan melepaskan radikal bebas oksigen yang merangsang pelepasan sitokin inflamasi. Peningkatan tekanan kapiler intraglomerular juga menghasilkan jaringan parut dan akhirnya menjadi sumbatan glomerulus. Kerusakan berlanjut pada sel epitel tubulus, dikombinasikan dengan cedera kapiler glomerulus, menyebabkan fibrosis tubulointerstitial, yang merupakan ciri khas CKD (Schaer \& Gashcen 2016).

Patofisiologi CKD dapat terjadi pada tingkat organ dan sistemik. CKD tingkat renal berupa perubahan patologis rusaknya nefron dan penurunan GFR. Penurunan fungsi GFR menghasilkan peningkatan konsentrasi zat seperti ureum dalam plasma darah. Gangguan berupa sindrom uremia yaitu ketidakseimbangan natrium dan air, anemia, intoleransi kar- bohidrat, gangguan neurologis, gangguan pencernaan, osteodistrofi, ketidakmampuan imunologis, dan asidosis metabolik (Nelson \& Couto 2013). Gejala seperti anoreksia, mual, dan letargi sering ditemukan pada pasien uremia mungkin disebabkan oleh asidosis (Grettha 2008).

Pengobatan CKD pada kucing memerhatikan asidosis metabolik, proteinuria, hipertensi, dehidrasi, kelainan elektrolit (hiperfosfatemia, hipokalemia, hiperkalemia), hiperparatiroidisme sekunder, pengapuran dan anoreksia, mual dan muntah, protein: malnutrisi kalori dan anemia (Little 2012). Terapi untuk mencegah atau mengobati komplikasi, penurunan fungsi ginjal, memperlambat hilangnya fungsi ginjal (Syme et al. 2016). Ringer laktat sebagai sumber energi yang dikonversi dari asetat menjadi bikarbonat dalam menangani asidosis. Kondisi asidosis terjadi ketika produksi asam ditubuh berlebihan atau saat ginjal tidak mampu membuang asam (August 2009). Pemberian gastroprotektan sebagai penanganan masalah gastrointestinal (Dowd et al. 2016). Antibiotik digunakan sebagai antisipasi infeksi sekunder yang muncul selama perjalanan penyakit. Pemberian suplemen untuk ginjal serta diet pakan diperlukan dalam pemeliaraan.

\section{- SIMPULAN}

Kucing Kiabi didiagnosis chronic kidney disease berdasarkan pada hasil temuan klinis dan konfirmasi pemeriksaan penunjang. Terapi yang diberikan berupa pengobatan suportif kerja ginjal, mencegah infeksi sekunder dan proteksi terhadap saluran pencernaan.

\section{- INFORMASI PENULIS}

\section{Penulis Korespondensi}

*TW: widyaputritiara@ub.ac.id

Bagian Penyakit Dalam, Laboratorium Klinik Hewan Pendidikan, Fakultas Kedokteran Hewan Hewan, Universitas Brawijaya, Malang, Jawa Timur, INDONESIA

\section{- PUSTAKA ACUAN}

August JR. 2009. Consultation in Feline Internal Medicine, Volume 6. Saunders Elsevier. China. 300-764.

Colville T, Bassert JM. 2016. Clinical Anatomy and Physiology for Veterinary Technicians, 3rd Edition. Missouri: Elsevier Inc.

Cornell Feline Health Center. 2019. Chronic Kidney Disease. Cornell University: New York.

Dowd FJ, Johnson B, Mariotti A. 2016. Pharmacology and Therapeutics for Dentistry 7th Edition. Saunders Elsevier. USA. 413

Foster JD. 2013. Canine Chronic Kidney Disease: Current Diagnostics \& Goals for Long-term Management. Today's Veterinary Practice: 21-26

Geetha D. 2008. Poststreptococcal Glomerulonephritis. http://emedicine.medscape.com/artikel/240337-overview. [20 Februari 2021]

International Renal Interest Society [IRIS]. 2017. Treatment Recommendations for CKD in Cats. London: Elanco Animal Health

Little ES. 2012. The Cat: Clinical Medicine and Management. Elsevier Saunders. United Kingdom.

Nelson R, Couto G. 2014. Small Animal Internal Medicine 5th Edition. California

Schaer M, Gaschen F. 2016. Clinical Medicine of the Dog and Cat, $3^{\text {rd }}$ Edition. CRC Press. USA. 363-786.

Syme HM, Markwell PJ, Pfeiffer D, Elliott J. 2006. Survival of cats with naturally occurring chronic renal failure is related to severity of proteinuria. Journal of Veterinary Internal Medicine 20(3):528-535. 